\title{
Penerapan Model Pembelajaran Kooperatif Tipe Think Talk Write (TTW) Untuk Meningkatkan Hasil Belajar Siswa Kelas VIII D SMPN 1 Mangaran Situbondo

\author{
(Online Examination Tryout Application for Senior and Vocational High \\ School Students)
}

\author{
Dian Iftitah Ummul Khairah, Imam Mudakir, Bevo Wahono \\ Pendidikan Biolgi, Fakultas Keguruan dan Ilmu Pendidikan, Universitas Jember \\ Jalan Kalimantan 37, Jember 68121 \\ E-mail:imam mudakir@yahoo.com
}

\begin{abstract}
Abstrak
Penelitian ini bertujuan untuk meningkatkan hasil belajar siswa dengan menerapkan model pembelajaran kooperatif tipe Think, Talk, Write (TTW). Model Pembelajaran kooperatif tipe Think, Talk, Write (TTW) terdiri dari tiga tahapan yaitu Think (Berpikir), Talk (berbicara), Write (menulis) yang diterapkan pada siswa kelas VIII-D SMPN 1 Mangaran Situbondo. Penelitian ini adalah penelitian tindakan kelas yang dilakukan dalam 2 siklus yaitu siklus I dan siklus II. Data penelitian yang didapatkan berasal dari observasi, wawancara dan tes. Hasil penelitian menunjukkan bahwa peningkatan hasil belajar siswa pada ranah kognitif dari pra siklus ke siklus I mengalami peningkatan sebesar 7,8 dan dari siklus I ke siklus II mengalami peningkatan sebesar 6. Berdasarkan penelitian ini, model pembelajaran kooperatif tipe Think, Talk, Write (TTW) dapat digunakan guru untuk meningkatkan hasilbelajar siswa.
\end{abstract}

Kata Kunci: Hasil belajar siswa, Model pembelajaran kooperatif tipe Think, Talk, Write (TTW)

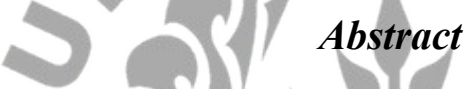

This study aims to improve students' learning Outcome by applying Think, Talk, Write (TTW) as a cooperative learning model. The Think, Talk, Write (TTW) model consists of three stages: Think, Talk, Write (TTW) that were applied to VIII-D students of SMPN 1 Mangaran Situbondo. This research is a classroom action research that was conducted in 2 cycles; cycle I and cycle II. The research data obtained from observation, interview and test. The results showed that the improvement of students' learning achievement in the cognitive domain from pre cycle to cycle I was increased by 7.8 and from cycle I to cycle II was increased by 6. Based on this research,Think, Talk, Write (TTW) as a cooperative learning modelcan be used by teachers to improve students' learning outcome.

Keywords: Student learning outcome, cooperative learning model Think, Talk, Write (TTW)

\section{Pendahuluan}

Kegiatan belajar merupakan kegiatan paling pokok dari keseluruhan proses pendidikan di sekolah. [1] belajar adalah suatu proses usaha yang dilakukan seseorang untuk memperoleh suatu perubahan tingkah laku yang baru secara keseluruhan sebagai hasil pengalamannya sendiri dalam interaksi dengan lingkungannya. Pembelajaran merupakan proses kerja sama antara guru dan siswa dalam memanfaatkan segala potensi dan sumber yang ada baik potensi yang bersumber dari dalam diri siswa itu sendiri baik minat, bakat dan kemampuan dasar yang dimiliki termasuk gaya belajar maupun potensi yang ada diluar diri siswa seperti lingkungan, sarana dan sumber belajar sebagai upaya untuk mencapai tujuan belajar tertentu [2].

Berdasarkan hasil wawancara dengan guru mata pelajaran IPA kelas VIII SMP 1 Mangaran Situbondo, diketahui bahwa guru mata pelajaran IPA masih menggunakan metode ceramah. Dari nilai rata-rata kelas tersebut diketahui bahwa kelas VIII D memiliki hasil belajar paling rendah. Rendahnya hasil belajar siswa yang terjadi pada kelas VIII D dikarenakan siswa kurang bersemangat sehingga siswa cenderung pasif pada saat proses pembelajaran berlangsung. Keadaan siswa yang cenderung pasif dan hanya menerima pengajaran dari guru dapat menjadikan pembelajaran yang diikuti oleh siswa tidak bermakna serta kurangnya proses berpikir selama pembelajaran berlangsung.

- Berdasarkan uaraian permasalahan diatas maka dibutuhkan model pembelajaran yang dapat memicu siswa untuk meningkatkan hasil belajar dan kemampuan berpikir kritis. Salah satu cara agar siswa lebih aktif yaitu dengan menerapkan model pembelajaran kooperatif. [3] Model pembelajaran kooperatif merupakan suatu pembelajaran yang dilakukan bersama-sama dengan saling membantu satu sama lainnya sebagai satu kelompok atau satu tim. Pembelajaran ini akan memberikan kesempatan siswa untuk mendiskusikan masalah, mendengarkan pendapat orang lain dan memacu siswa untuk bekerja sama, saling membantu menyelesaikan permasalahan. Oleh karena itu model pembelajaran kooperatif dapat melibatkan siswa secara aktif dalam mengembangkan pengetahuan, sikap dan keterampilan sosial untuk diterapkan dalam kehidupan di masyarakat. 
Peneliti mencoba membantu menyelesaikan permasalahan dengan menerapkan pembelajaran kooperatif tipe Think, Talk, Write (TTW) untuk meningkatkan hasil belajar siswa SMPN 1 Mangaran Situbondo. Model pembelajaran kooperatif dengan tipe Think, Talk, Write (TTW) merupakan model pembelajaran yang memiliki tahap-tahap mulai dari membaca, memaparkan dan menulis dalam bentuk catatan.

Menurut Ansari [4] model ini diawali dengan berpikir, berbicara dan menulis. Model pembelajaran ini dimulai dari proses berpikir dengan membaca suatu teks permasalahan dan menuliskan dalam catatan kecil (Think), hal ini dapat dapat melatih kemampuan berpikir siswa karena pada tahap ini siswa melalui proses awal dengan berpikir dari sebuah permasalahan dan dituangkan dalam sebuah catatan. (Talk), hal ini dapat memaparkan ide-ide yang telah dipikirkan dari sebuah permasalahan sehingga siswa dapat saling berpendapat antar kelompok dan siswa dapat mengetahui suatu pemecahan masalah yang lebih spesifik. (Write) pada tahap akhir ini siswa bersama guru membahas kembali permasalahan dan membuat kesimpulan dari sebuah permasalahan setelah itu menuliskan hasil diskusi.

Berdasarkan latar belakang maka dilakukan penelitian dengan judul Penerapan Model Pembelajaran kooperatif dengan Tipe Think, Talk, Write (TTW) untuk Meningkatkan Hasil Belajar Siswa di SMP 1Mangaran Situbondo Kelas VIII-D Materi Sistem Pernapasan. Berdasarkan uraian latar pada belakang, maka rumusan masalah pada penelitian ini adalah bagaimanakah peningkatan hasil belajar dengan penerapan model pembelajaran tipe Think, Talk, Write (TTW) pada siswa kelas VIII D SMPN1 Mangaran Situbondo?

\section{Metode Penelitian}

Jenis penelitian ini adalah Penelitian Tindakan Kelas (Classroom Action Research) yang dilaksanakan di Sekolah Menengah Pertama (SMP) Negeri 1 Mangaran Situbondo. Penelitian ini dilaksanakan mulai bulan April sampai dengan Mei 2017 semester genap tahun pelajaran 2016/2017. Subjek penelitian ini ialah siswa kelas VIII-D semester genap tahun ajaran 2016/2017 dengan jumlah siswa sebanyak 22 siswa. Pengumpulan data dilakukan dengan metode obervasi, wawancara dan tes. Penelitian ini dilakukan sebanyak dua siklus yang terdiri dari tahap perencanaan, pelaksanaan tindakan, observasi dan refleksi. Perhitungan peningkatan hasil belajar diukur dengan memberikan tes pada setiap akhir siklus satu dan siklus dua, dengan kriteria ketuntasan minimal 75 (disesuaikan dengan KKM SMP Negeri 1 Mangaran Situbondo).

\section{Hasil Penelitian dan Pembahasan}

\section{Hasil Belajar Kognitif}

Tabel 1. Peningkatan Hasil Belajar Kognitif Siswa

\begin{tabular}{|c|c|c|c|c|}
\hline Siklus & $\begin{array}{c}\text { Siswa } \\
\text { Tuntas }\end{array}$ & $\begin{array}{c}\text { Siswa Tidak } \\
\text { Tuntas }\end{array}$ & $\begin{array}{c}\text { Rata-rata } \\
\text { Kelas } \pm \text { SD }\end{array}$ & $\begin{array}{c}\text { Persentase } \\
\text { Ketuntasan }\end{array}$ \\
\hline Pra Siklus & 6 & 16 & $64,19 \pm 27$ & $27 \%$ \\
\hline I & 10 & 12 & $72 \pm 22,6$ & $45 \%$ \\
\hline
\end{tabular}

\begin{tabular}{|c|c|c|c|c|}
\hline II & 20 & 2 & $78 \pm 18,3$ & $95 \%$ \\
\hline \multicolumn{3}{|c|}{ Peningkatan Prasiklus ke Siklus I } & 7,8 & $18 \%$ \\
\hline \multicolumn{3}{|c|}{ Peningkatan Siklus I ke Siklus II } & 6 & $50 \%$ \\
\hline
\end{tabular}

Berdasarkan Tabel 1 tersebut menunjukkan bahwa ada peningkatan hasil belajar siswa dari pra siklus ke siklus I dan Siklus II. Jumlah siswa yang tuntas pasa pra siklus adalah 6 siswa dari 22 siswa kelas VII D dengan persentase $27 \%$ dengan rata-rata 64,19. Pada siklus I jumlah siswa yang tuntas adalah 10 siswa atau $45 \%$ dari jumalah siswa kelas VIII D dengan rata-rata 72. Pada siklus II jumlah siswa yang tuntas adalah 20 siswa atau $91 \%$ dari jumalah siswa kelas VIII D dengan rata-rata 78 Sehingga nilai rata-rata klasikal dari pra siklus ke siklus I terdapat peningkatan sebesar 7,8 sedangkan peningkatan hasill belajar dari siklus I ke siklus II sebesar 6 .

\section{Hasil Belajar Afektif}

Tabel 2. Peningkatan hasil belajar afektif

\begin{tabular}{|l|c|c|c|}
\hline \multicolumn{1}{|c|}{ Sikap } & Siklus I & Siklus II & Peningkatan \\
\hline Disiplin & 93,5 & 97,0 & 3,5 \\
\hline Tanggung Jawab & 87,5 & 95,0 & 7,5 \\
\hline Kerja Sama & 77,0 & 84,0 & 7,0 \\
\hline $\begin{array}{l}\text { Aktif Bertanya dan } \\
\text { Mengeluarkan Pendapat }\end{array}$ & 70,5 & 76,5 & 6,0 \\
\hline Rata-rata & 82,125 & 88,125 & 6,0 \\
\hline
\end{tabular}

Berdasarkan Tabel 2 terlihat bahwa hasil belajar afektif siswa terdapat peningkatan dari Siklus I ke siklus II. Pada sikap dísiplin, nilai siklus I 93,5 meningat sebesar 3,5 pada siklus II menjadi 97. Pada sikap tanggung jawab, nilai siklus I 87,5 meningat sebesar 7,5 pada siklus II menjadi 95. Pada sikap kerja sama, nilai siklus I 77 meningat sebesar 7 pada siklus II menjadi 84. Pada sikap aktif bertanya dan mengeluarkan pendapat, nilai siklus I 70,5 meningkat sebesar 6 pada siklus II menjadi 76,5.

Hasil Belajar

Pada hasil belajar kognitif siswa mengalami peningkatan dari pra siklus ke Siklus I sampai siklus II. Jumlah siswa yang tuntas pasa pra siklus adalah 6 siswa dari 22 siswa kelas VII D dengan persentase $27 \%$ dengan rata-rata 64,19. Pada siklus I jumlah siswa yang tuntas adalah 10 siswa atau $45 \%$ dari jumlah siswa kelas VIII D dengan rata-rata 72 . Pada siklus II jumlah siswa yang tuntas adalah 20 siswa atau $91 \%$ dari jumalah siswa kelas VIII D dengan rata-rata 78 Sehingga nilai rata-rata klasikal dari pra siklus ke siklus I terdapat peningkatan sebesar 7,8 sedangkan peningkatan hasill belajar dari siklus I ke siklus II sebesar 6. Hasil belajar merupakan kemampuan yang dimiliki siswa setelah mengikuti pembelajaran [5]. Prestasi belajar adalah usaha maksimal yang dicapai oleh seseorang setelah melaksanakan usahausaha belajar [6]. Pada tahap think siswa memulai dengan berpikir dan mengaitkan permasalahan yang akan dipecahkan dengan informasi yang telah ketahui sebelumnya sehingga pada tahap ini siswa mulai mencari jawaban dari permasalahan yang akan dipecahkan sehingga hal ini dapat menimbulkan suatu. [7] menyatakan salah satu pandangan tentang proses pembelajaran yang menyatakan bahwa dalam 
proses belajar (perolehan pengetahuan) diawali dengan terjadinya konflik kognitif yang hanya dapat diatasi melalui pengetahuan diri dan pada akhir proses belajar pengetahuan akan dibangun oleh anak melalui pengalamannya dari hasil interkasi dengan lingkungannya. Menurut [8] terjadinya proses pemahaman mengenai suatu peristiwa berdasarkan pengetahuan yang ada dalam diri siswa.

Pada tahap Talk Siswa bergabung dengan anggota kelompok untuk berdiskusi dan saling memberikan pendapat dari hasil pemikiran pada saat mengerjakan Lembar Kerja Siswa (LKS) sehingga pada tahap ini siswa dapat mendapatkan informasi baru antar anggota kelomponya sehingga siswa dapat memecahkan suatu permasalahan secara bersama. menurut [9] mengemukakan metode diskusi adalah suatu cara penyajian bahan pengajaran dengan guru memberikan kesempatan kepada siswa atau kelompokkelompok untuk mengadakan perbincangan ilmiah guna mengumpulkan pendapat, membuat kesimpulan atau menyusun ke berbagai alternatif pemecahan suatu masalah sehingga siswa dapat lebih memahami terhadap materi yang sedang dipelajari, hal ini dapat meningkatkan hasil belajar siswa. Menurut [10] bahwa ketika siswa berkelompok secara heterogen, akan tercipta suasana belajar dalam kelompok, dimana siswa yang mempunyai kecerdasan tinggi dapat membantu guru dalam membimbing siswa yang memiliki kemampuan sedang dan sebagai penggerak pemecah masalah kelompok.

Pada tahap Write siswa menuliskan kesimpulan dari sebuah permasalahan, hal ini dapat membuat siswa semakin memahami terhadap materi yang sedang dipelajari, sehingga siswa pada saat ulangan akhir siskus mendapatkan yang semakin meningkat hal ini sesusi dengan yang diungkapkan oleh [11] bahwa hasil belajar siswa meningkat pada tiap siklusnya. Refleksi yang dilakukan bertujuan untuk memperbaiki kekurangan yang ada pada siklus sebelumnya sehingga pada siklus selanjutnya menjadi lebih baik, Sebagaimana menurut [12] berpikir dan berdiskusi merupakan langkah penting dalam proses membawa pemahaman siswa ke dalam sebuah tulisan. Ketika menulis siswa melakukan aktivitas berpikir dan merupakan kegiatan pengekspresian hasil pemikirannya. Selain itu menulis adalah sebuah kendaraan dimana siswa dapat dengan mudah mengekspresikan pemikiran kritis mereka [13]

Pada hasil belajar afektif siswa mengalami peningkatan dari siklus I sampai siklus II. Pada sikap disiplin, nilai siklus I 93,5 meningat sebesar 3,5 pada siklus II menjadi 97. Pada sikap tanggung jawab, nilai siklus I 87,5 meningat sebesar 7,5 pada siklus II menjadi 95. Pada sikap kerja sama, nilai siklus I 77 meningat sebesar 7 pada siklus II menjadi 84 . Pada sikap aktif bertanya dan mengeluarkan pendapat, nilai siklus I 70,5 meningat sebesar 6 pada siklus II menjadi 76,5. Secara klasikal hasil belajar afektif pada siklus I sebesar 82,125 dengan kroteria sangat baik. Pada siklus II menunjukkan hasil belajar afektif siswa sebesar 88,125 dengan kriteria sangat baik sehingga dari siklus I ke siklus II terdapat peningkatan sebesar 6 .

Peningkatan hasil belajar afektif dilihat dari sikap siswa selama pembelajaran berlangung. Pada tahap Think siswa sudah mulai bersedia untuk mengerjakan LKS yang diberikan oleh guru walaupun pada tahap think ini siswa pada siklus I masih terdapat beberapa siswa yang belum bisa membuat rumusan masalah hal ini dikarenakan siswa belum terbiasa dengan membuat rumusan masalah akan tetapi pada siklus II siswa sudah bisa dalam membuat rumusan masalah. Pada tahap Talk Siswa sudah baik dalam bekerjasa sama antar anggota kelompok. Siswa dapat berinteraksi dengan baik dan melakukan diskusi dengan lancer sehingga permasalahan dapat terpecahkan dengan baik pula. Pada tahap ini pula siswa sudah dapat menyampaikan pendapat serta bertanya kepada guru terhadap yang belum siswa ketahui. Pada tahap write siswa mencatat hasil diskusi, tahap ini adalah tahap terakhir dari model pembelajaran tipe Think, Talk, Write (TTW) siswa melakukan setiap tahapan dengan baik dan bertanggung jawab dengan tugas LKS yang diberikan oleh guru. Sehingga hasil belajar afektif siswa setiap siklus meningkat ini semakin meninggkat dengan adanya perubahan yang lebih baik dari siklus I ke siklus II . Hal ini sesuai dengan prinsip perbedaan individual yang mempengaruhi cara dan hasil belajar siswa, yang membutuhkan perhatian dan bimbingan secara individual sehingga perbedaan kemampuan siswa dapat terlayani [14].

Model Pembelajaran Tipe Think, Talk, Write (TTW) lebih menekankan kepada proses pembelajaran dalam memperoleh informasi dan memahami materi pembelajaran yang diberikan oleh guru yang disempurnakan dengan menggunakan berbagai media pembelajaran yang memudahkan siswa untuk bersikap aktif dan menemukan halhal baru diberikan guru [15].

\section{Kesimpulan dan Saran}

1. Kesimpulan

Terdapat peningkatan pada hasil belajar siswa dengan penerapan model pembeljaran kooperatif dengan tipe Think, Talk, Write (TTW) pada siswa kelas VIII D SMP Negeri 1 Mangaran Situbondo tahun pelajaran 2016/1017. Rata-rata nilai hasil belajar kognitif pra siklus sebesar 64,19, siklus I sebesar 72 dan siklus II sebesar 78 . Sehingga dari pra siklus ke siklus I mengalami peningkatan 7,8 dan dari siklus I ke siklus II mengalami peningkatan sebesar 6 . Rata-rata nilai hasil belajar afektif siklus I sebesar 82,125 dan siklus II sebesar 88,125. Sehingga siklus I ke siklus II mengalami peningkatan sebesar 6 .

2. Saran

Perlu dilakukan penelitian lebih lanjut mengenai model pembelajaran kooperatif tipe Think, Talk, Write (TTW) pada materi yang berbeda dan jumlah pertemuan yang lebih banyak sehingga guru atau pengajar lain dapat menerapkannya secara maksimal untuk meningkatkan hasil belajar siswa.

\section{Daftar Pustaka}

[1] Slameto, 1995. Belajar dan faktor-faktor yang mempengaruhi. Jakarta: Rineke Cipta.

[2] Sanjaya, W, 2008. Strategi Pembelajaran Berorientasi Standar Proses Pendidikan. Jakarta : Kencana Prenada Media Group

[3] Isjoni, 2009. Pembelajaran kooperatif meningkatkan Kecerdasan Komunikasi Antar Peserta Didik. Yogyakarta: Pustaka Belajar 
[4] Ansari,B. I, 2003. Menumbuhkembangkan Kemampuan Pemahaman dan Komunikasi Matematis Siswa SMU melalui Strategi ThinkTalk-Write. Disertasipada PPs UPI Bandung: Tidak diterbitkan.

[5] Sudjana. (1991). Dasar - Dasar Proses Belajar Mengaja. Bandung: Sinar Baru Algensindo.

[6] Gunarso.1993. Bagaimana Bimbingan dan Penyuluhan Belajar di Sekolah, Surabaya : Usaha Nasional.

[7] Karli, 2003. Implementasi Kurikulum Berbasis Kompetensi, Bandung: Bina Media Informasi

[8] Jufri, W. (2013). Belajar dan Pembelajarn Sains. Bandung: Pustaka Reka Cipta.

[9] Suryosubroto. 1997. Proses Belajar Mengajar Di Sekolah. Jakarta: PT Rineksa Cipta.

[10] Yamin, 2010. Strategi Pembelajaran berbasis kompetensi. Jakarta: Gaung Persada Press

[11] Sari, A.D.P. 2011. “ Penggunaan Model Inkuiri Disertai Media Pembelajaran Vidio Untuk Meningkatkan Aktifitas Belajar dan Hasil Belajar Fisika Siswa Kelasn VIII-B MTS Negeri Jember 1". Tidak Diterbitkan. Skripsi. Jember: Universitas Jember

[12] Huinker, D. \& Laughlin, C. (1996). Talk Your Way Into Writing. Dalam Communication in Mathematics K-12 and Beyond. The National Counsil of Teacher of Mathematics.

[13] Dixon, F., Cassady, J., \& Cross, T., (2005). Effects of Technology on Critical Thinking and Essay Writing and Gifted Adolescents. The Journal of Secondary Gifted Education,Summer, XVI (4), hlm. 180189.

[14] Dimyati, Mudjiono, 2006. Belajar dan Pembelajaran. Jakarta: PT Rineka Cipta.

[15] Komang, I \& Dkk (2015).Desain Pesan (Kajian Analitis Desain Visual). Yogyakarta: Graha Ilmu.

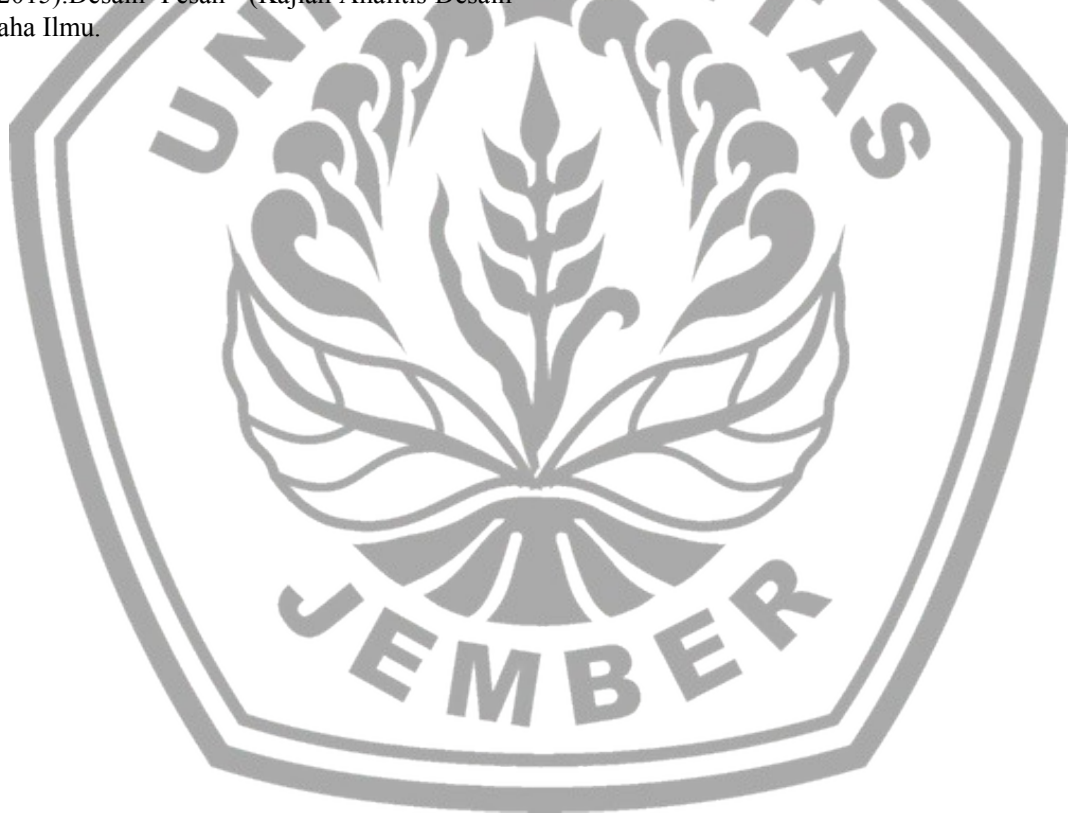

